\author{
이중램제트(이중연소/이중모드)엔진을 위한 \\ 램제트/스크램제트의 작동영역분배 및 성능민감도분석 \\ Part II. 성능민감도 \\ 김선경*, 전창수**, 성홍계**, 변종렬***, 윤현걸***
}

\title{
Performance Load Balancing and Sensitivity Analysis of Ramjet/Scramjet for Dual-Combustion/Dual-Mode Ramjet Engine Part II. Performance Sensitivity
}

Sun-Kyoung Kim*, Chang-Soo Jeon**, Hong-Gye Sung**, Jong-Ryul Byen*** and Hyun-Gull Yoon***

\begin{abstract}
In order to investigate the operating conditions and major design parameters of a dual ramjet propulsion system, an theoretical analysis of ramjet and scramjet propulsion systems was performed. The performance characteristics of each engine are delivered by thermo-dynamical cycle analysis, considering loss effects in a real engine. The performance sensitivity analysis is conducted by investigating various performance parameters, such as an intake efficiency, combustor inlet Mach number, configuration of the combustor, fuel flow rate, and exhaust nozzle efficiency. Based on these analysis results, the processes of application to dual ramjet cycle engines are specified.
\end{abstract}

$$
\text { 초 록 }
$$

이중램제트(이중연소 및 이중모드) 추진기관의 작동특성 및 주요 설계인자를 파악하기 위하 여 램제트/스크램제트 추진기관에 대한 공기 및 열역학적 관점에서 이론적인 분석을 수행하 였다. 엔진의 효율계수를 적용한 열역학 사이클 해석을 수행하여 각 추진기관의 성능특성을 파악하고, 흡입구 성능 특성, 연소기 입구 마하수, 연소기 형상 및 당량비(연료분사량)에 따른 성능민감도를 분석하였다. 이를 바탕으로 이중램제트 추진기관의 성능설계방향을 제안한다.

Key Words : Ramjet(램제트), Scramjet(스크램제트), Total Pressure Recovery(전압력 회 복계수), Operating Limitations(작동한계)

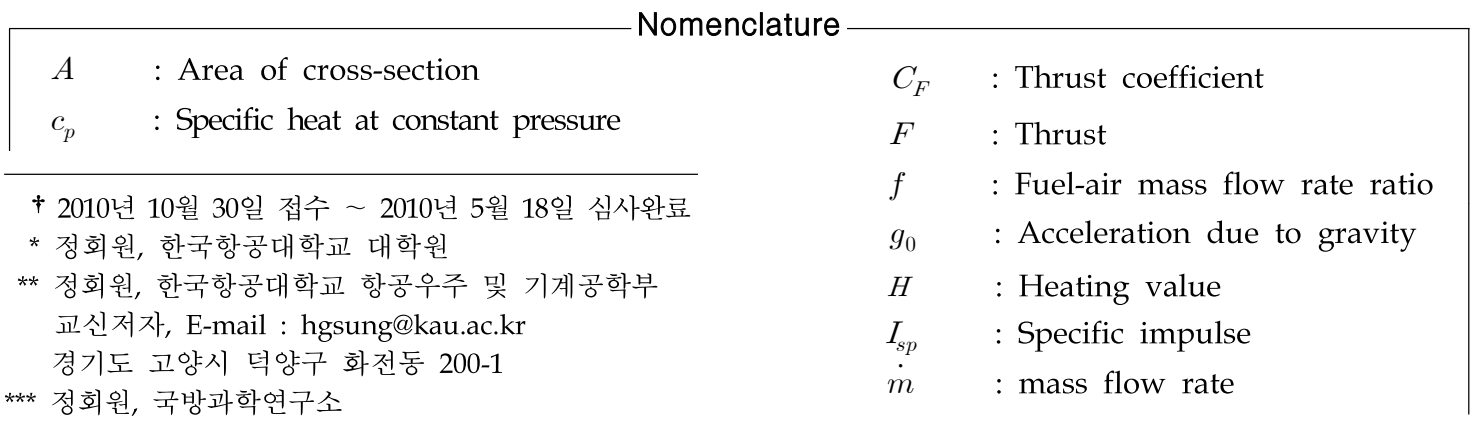




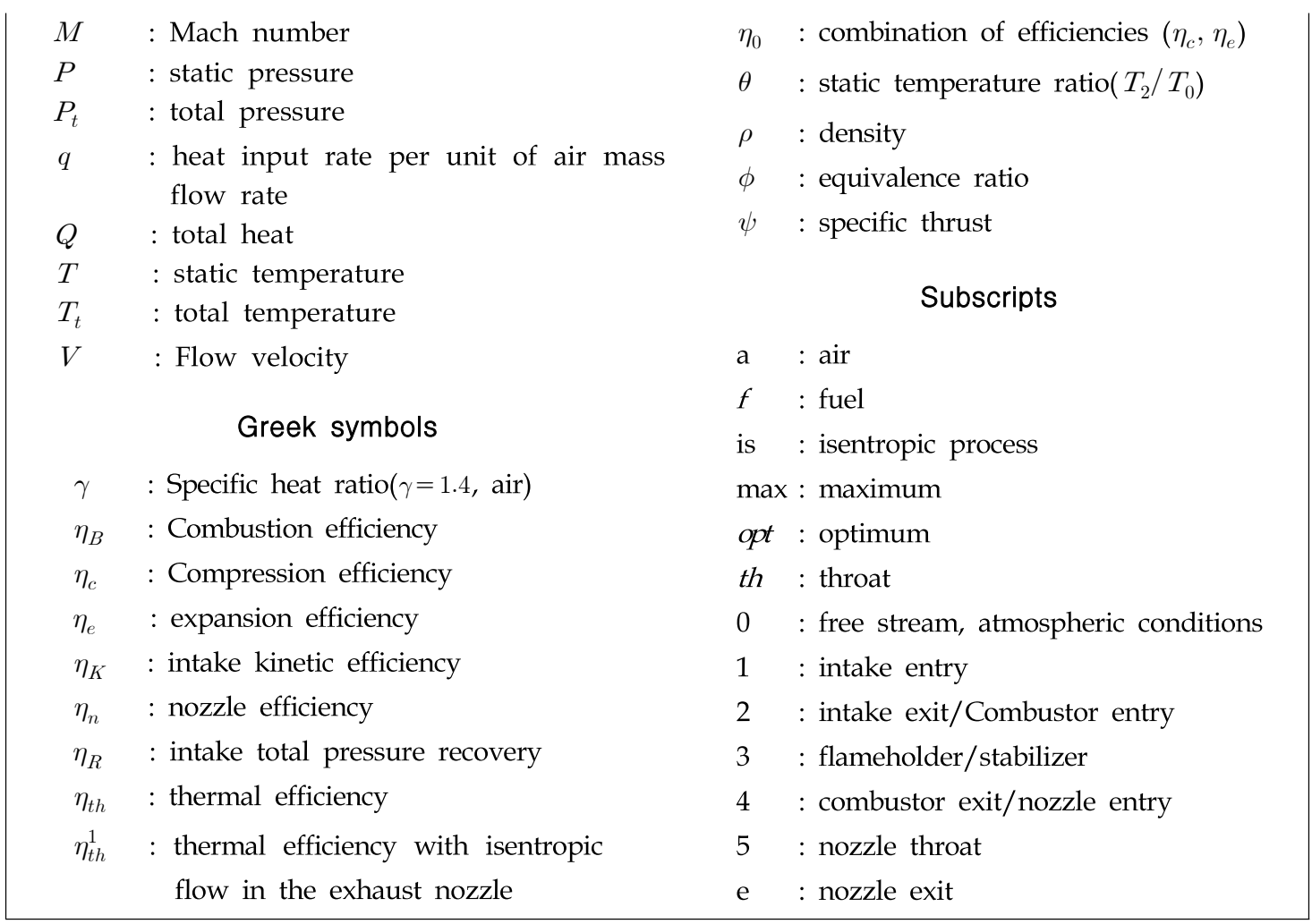

\section{I. 서 론}

이중램제트 추진시스템은 초음속 비행영역에 서는 램제트 엔진을, 극초음속 비행영역에서는 스크램제트 엔진을 적용함으로써, 단일 비행체로 광범위한 비행 마하수를 충족시킬 수 있을 뿐만 아니라 다른 추진기관에 비해 시스템이 단순하고 재사용이 가능한 공기흡입식 추진기관의 장점을 가지고 있다. 이러한 이중램제트 추진기관은 아직 실용 기술 개발보다는 기술개발을 위한 개념연구 를 위주로 다수의 연구가 이루어지고 있다[1-3].

이중램제트 추진기관의 개발을 위해서는 우선 적으로 램제트 및 스크램제트 추진기관 개발기술 이 확보되어야 한다. 이중램제트 추진기관은 다 른 공기흡입식 추진기관들에 비해 구조가 단순하 여 초음속/극초음속 순항 추진기관으로서의 적 용에 큰 장점을 가지고 있으나 초음속/극초음속 의 유동을 공기역학적인 방식으로 압축하여 연소 실로 공급하는 형태로 비행속도 및 자세 등에 민 감하며, 구조적인 단순화로 인해 엔진의 각 구성 품의 성능특성이 엔진 작동에 매우 큰 영향을 미 치므로 실용화에 어려움이 있다.

본 연구에서는 이론적인 해석을 기반으로 램제
트/스크램제트 추진기관의 물리적인 특성을 파악 하고 기본개념을 정립한다[2-5]. 또한 각 엔진의 성능인자의 변화에 따른 엔진성능특성의 민감도 를 파악하여 램제트/스크램제트 엔진을 이용한 이중램제트 엔진의 주요 설계인자를 파악한다.

\section{II. 본 론}

\section{1 사이클 해석}

램제트/스크램제트 추진기관의 성능인자를 파 악하고 성능변수들에 미치는 영향을 살펴보기 위 해 사이클 해석을 수행한다. 램제트 추진기관의 해석에 적용된 상태량 표기법은 Fig. 1과 같다.

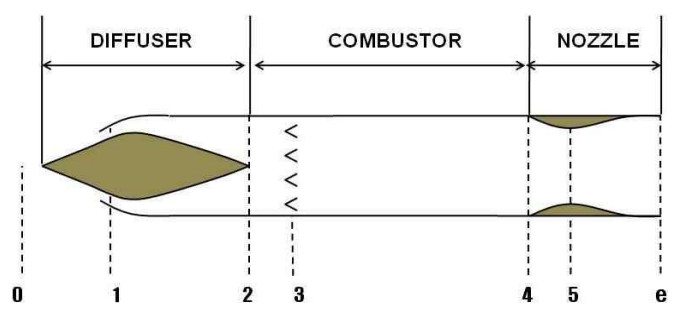

Fig. 1. Schematic Diagram of a Ramjet Engine 


\subsection{1 흡입구}

공기의 램압축을 이용하는 램제트와 스크램제 트 엔진의 성능에 있어서 흡입구 효율은 주요한 변수이다. 따라서 램제트/스크램제트 엔진의 성 능을 보장하기 위해서는 전 비행영역에 걸쳐 강 건한 흡입구를 설계하는 것이 매우 중요하다.

흡입구에서 발생하는 손실은 주로 충격파와 점성효과로 인해 발생한다. 본 해석에서의 흡입 구 영역은 Fig. 1에서 위치0에서 위치2에 해당하 는 영역으로 초음속 및 극초음속으로 유입되는 공기의 속도를 감속시킴으로서 정압력 및 온도의 상승을 수반한다. 또한 충격파 및 마찰 등으로 인한 전압력의 감소가 발생한다.

일반적으로 램제트 엔진에서 흡입구의 효율은 전압력 회복계수와 kinetic energy $(\mathrm{KE})$ 효율을 사 용하여 나타낸다. 전압력 회복계수 $\left(\eta_{R}\right)$ 의 정의는 식 (1)과 같이 자유흐름에서의 전압력과 흡입구 출구에서의 전압력의 비로 나타난다.

$$
\eta_{R}=\frac{P_{t 2}}{P_{t 0}}
$$

흡입구의 Kinetic energy $(\mathrm{KE})$ 효율 $\eta_{K}$ 는 다음 과 같이 표현된다[4].

$$
\eta_{K}=\frac{\left(V_{0}\right)_{i s}^{2}}{V_{0}^{2}}=1-\frac{\eta_{R}^{-\frac{\gamma-1}{\gamma}}-1}{\frac{\gamma-1}{2} M_{0}^{2}}
$$

여기서 $V_{0}$ 는 실제 비행속도이고, $\left(V_{0}\right)_{i s}$ 는 흡 입구 출구에서 대기로 등엔트로피 팽창을 통해 얻어지는 속도이다.

Fig. 2는 전압력 회복계수와 $\mathrm{KE}$ 효율의 관계를 나타낸다. 주어진 비행 마하수에 대하여, 흡입구 $\mathrm{KE}$ 효율은 전압력회복계수가 증가함에 따라 증가 하며, 비행 마하수가 증가 할수록 전압력회복계 수에 영향을 받지 않으며 1 에 가까워짐을 확인할 수 있다.

흡입구로 들어오는 초음속의 공기는 충격파를 통과하면서 유속이 감소되고 정압력은 증가된다. 온도와 압력의 상승으로 인하여 압축 공기의 열 역학적 특성에 변화가 발생된다[6]. 특히 램제트 의 경우 경사충격파와 최종적으로 종말충격파를 발생시켜 초음속의 유동을 아음속으로 감속시킴 에 따라 급격한 온도/압력의 상승을 동반한다. 본 해석에서는 엔진 전영역에 대하여 $\gamma=1.4$ 로 일정하다고 가정하였으나 실제 압축공기의 열역 학적 특성은 각 위치에 따라 변화하며 이는 엔진 의 성능에도 영향을 미친다.

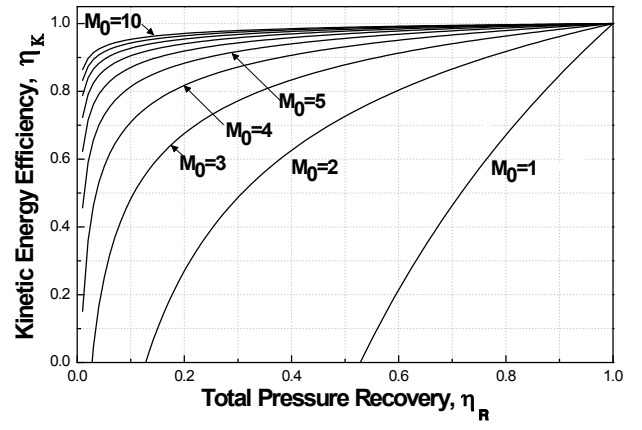

Fig. 2. Variation of KE Efficiency with Total Pressure Recovery

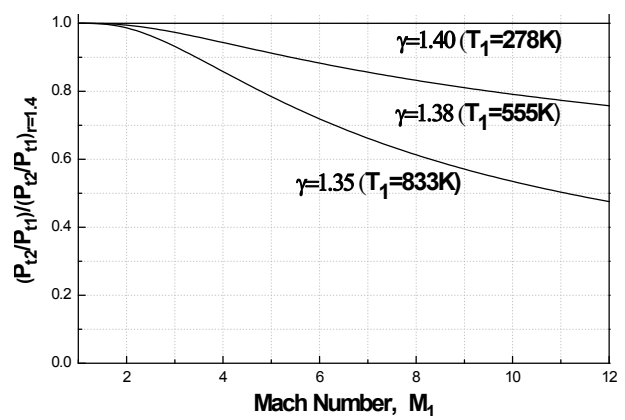

Fig. 3. Total pressure ratio for normal shock wave according to $\gamma$ variation

Fig. 3은 비열비 변화에 따른 수직 충격파를 통한 전압력비의 변화를 보여준다. 마하수가 증 가할수록 비열비 변화에 따른 전압력 손실이 증 가하는 것을 확인할 수 있으며 이는 극초음속으 로 갈수록 실제 기체의 영향이 중요하게 고려되 어야 함을 뜻한다.

\subsection{2 연소기}

연소기 내 전압력 손실은 크게 1)연소기 내부 의 마찰과 유동박리로 인한 손실, 2)초음속 유동 의 감속으로 인한 충격파 손실, 3 )높은 마하수에 서의 연소(열에너지 추가)로 인한 Rayleigh line 손실로 나타난다. 일반적인 가스터빈기관은 아음 속에서부터 낮은 초음속 영역까지 작동하며 연소 기 내 유동속도가 낮기 때문에 손실의 주원인은 위의 첫 번째 손실이 된다. 그러나 아음속 연소 를 하는 램제트의 경우 첫 번째와 세 번째 손실 이 중요하며, 스크램제트의 경우 초음속 연소로 인하여 위의 세 가지가 모두 연소기 전압력 손실 의 중요한 원인으로 고려된다.

본 해석에서는 일정한 단면적을 가지는 연소기 와 일정한 압력을 가지는 연소기 사이클 해석을 수행함으로써 연소기의 효율에 따른 성능민감도 를 분석한다. 일정한 압력의 연소기는 정압연소를 
가정한 이상적 브래이튼 사이클을 기반으로 하는 연소기로서 축방향으로 갈수록 단면적이 확산되 는 형상을 가지며, 일정한 단면적의 연소기는 유 도무기체계에 주로 적용되는 형상으로 엔진의 무 게와 항력을 줄일 수 있는 장점이 있다. 실제 연 소기는 위 두가지 중 적합한 연소기를 선택적으 로 적용하거다 두 가지의 특성을 혼용하여 엔진 의 개념설계 시 램제트와 스크램제트의 작동 영 역 분배를 결정하는데 유용하게 적용할 수 있다. 여기서 연소기 내 유동은 일정 상태량을 가지는 이상기체, 비점성 유동을 가정하였으며, 연료분사 에 의한 질량추가를 고려하였다.

일정한 단면적을 가지는 연소기의 입구와 출 구 상태량에 대한 전압력비와 전온도비는 식 (3)-(4)와 같이 연소기 입구 마하수와 출구 마하 수의 식으로 나타난다.

$$
\begin{gathered}
\frac{P_{t 4}}{P_{t 2}}=\frac{1+\gamma M_{2}^{2}}{1+\gamma M_{4}^{2}}\left[\frac{2+(\gamma-1) M_{4}^{2}}{2+(\gamma-1) M_{2}^{2}}\right]^{\frac{\gamma}{\gamma-1}} \\
\frac{T_{t 4}}{T_{t 2}}=\left[\frac{1+\gamma M_{2}^{2}}{1+\gamma M_{4}^{2}}\left(\frac{M_{4}}{M_{2}}\right)\right]^{2}\left[\frac{2+(\gamma-1) M_{4}^{2}}{2+(\gamma-1) M_{2}^{2}}\right] \frac{1}{(1+f)^{2}}
\end{gathered}
$$

일정한 압력을 가지는 연소기 내 전압력비와 전온도비는 식 (5)-(6)과 같다.

$$
\begin{gathered}
\frac{P_{t 4}}{P_{t 2}}=\left[\frac{2+(\gamma-1) M_{4}^{2}}{2+(\gamma-1) M_{2}^{2}}\right]^{\frac{\gamma}{\gamma-1}} \\
\frac{T_{t 4}}{T_{t 2}}=\left(\frac{M_{4}}{M_{2}}\right)^{2}\left[\frac{2+(\gamma-1) M_{4}^{2}}{2+(\gamma-1) M_{2}^{2}}\right] \frac{1}{(1+f)^{2}}
\end{gathered}
$$

\subsection{3 추진노즐}

추진노즐의 성능특성이 엔진 전체의 성능에 미치는 영향을 살펴보기 위하여 노즐의 효율계수 를 사용한다. 일반적으로 사용되는 추진 노즐의 효율계수는 식 (7)과 같이 정의된다.

$$
\eta_{n}=\frac{V_{e}^{2}}{\left(V_{e}\right)_{i s}^{2}}=\frac{1-\left(P_{0} / P_{t e}\right)^{\frac{\gamma-1}{\gamma}}}{1-\left(P_{0} / P_{t 4}\right)^{\frac{\gamma-1}{\gamma}}}
$$

여기서 $V_{e}$ 는 실제 노즐 출구에서의 속도이고, $\left(V_{e}\right)_{i s}$ 는 노즐 입구 정체조건에서 등엔트로피, 이 상 팽창을 통해 얻어진 속도이다.

따라서 위의 효율계수를 사용하여 추진노즐에 서의 전압력비는 식 (8) 같이 나타낼 수 있다.

$$
\frac{P_{t e}}{P_{t 4}}=\left[\eta_{n}+\left(1-\eta_{n}\right)\left(\frac{P_{t 4}}{P_{0}}\right)^{\frac{\gamma-1}{\gamma}}\right]^{-\frac{\gamma}{\gamma-1}}
$$

여기서 전압력 손실은 팽창비 $P_{t 4} / P_{0}$ 에 의존하 는데, 이 압력비는 흡입구와 연소기의 전압력비 로부터 식 (9)로 표현된다.

$$
\frac{P_{t 4}}{P_{0}}=\frac{P_{t 4}}{P_{t 2}} \eta_{R}\left(1+\frac{\gamma-1}{2} M_{0}^{2}\right)^{\frac{\gamma-1}{\gamma}}
$$

\section{2 해석 결과}

위의 사이클 해석이론을 기반으로 램제트/스 크램제의 각 성능인자의 영향에 따른 엔진의 성 능민감도를 파악한다. 램제트와 스크램제트 각각 의 성능민감도를 살펴보기 위하여 흡입구 효율, 연소실 형상 및 당량비, 연소기 입구 마하수, 추 진노즐의 효율을 주요성능인자로 선택하였으며, 각각이 성능에 미치는 영향을 해석하였다. 성능 해석에 적용된 대기조건과 연료특성, 효율특성 및 성능변수의 정의는 본 논문의 Part I 과 동일 하다[2].

\subsection{1 흡입구 손실의 영향}

엔진의 열효율에 미치는 흡입구의 손실에 의 한 영향을 살펴보기 위하여 노즐에서의 유동 손 실이 없다고 가정했을 때의 열효율 $\eta_{t h}^{1}$ 을 식 (10) 과 같이 정의한다[5].

$$
\begin{aligned}
\eta_{t h}^{1}= & \frac{V_{e, i s}^{2}-V_{0}^{2}}{2 q} \\
= & 1-\frac{2+(\gamma-1) M_{2}^{2}}{2+(\gamma-1) M_{0}^{2}}\left[1+\left(1-\eta_{k}\right) \frac{\gamma-1}{2} M_{0}^{2}\right] \\
& -\frac{\left(1-\eta_{k}\right)}{q / c_{p} T_{0}} \frac{\gamma-1}{2} M_{0}^{2}
\end{aligned}
$$

Fig. 4는 비행 마하수와 연소기 입구 마하수에 대하여 일정한 $\mathrm{KE}$ 효율 $\eta_{K}$ 에 따른 흡입구 손실

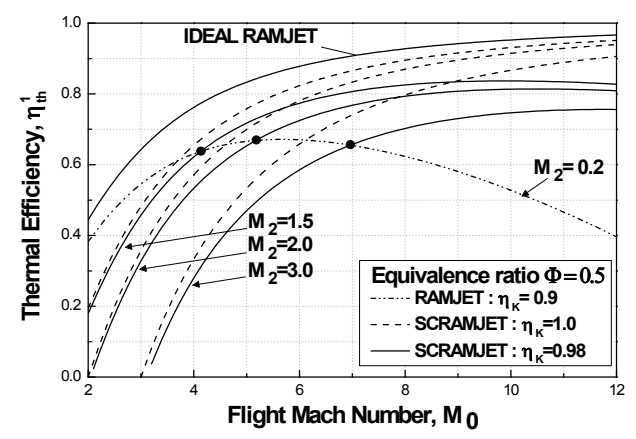

Fig. 4. Effect of Intake Losses on the Thermal Efficiency 
의 영향을 이상 램제트의 경우와 비교하여 나타 내었다. 램제트에 대해서는 $M_{2}=0.2$, 스크램제트 에 대해서는 $M_{2}=1.5 \sim 3.0$ 을 적용하였다. 램제 트의 경우 비행 마하수 약5에서 최대 열효율을 가지며 그 이상의 비행영역에서는 열효율이 급격 히 감소함을 알 수 있다. 또한 이상 램제트와 비 교할 때 흡입구 손실에 따른 열효율의 감소율이 비행마하수가 증가함에 따라 급격히 증가한다. 스크램제트는 초음속영역에서는 흡입구의 손실을 무시하여도 램제트보다 낮은 열효율을 갖는다. 그러나 비행마하수가 증가할수록 열효율은 점차 적으로 증가하여 램제트보다 높은 성능을 나타낸 다. 이는 극초음속 영역에서는 흡입구의 성능이 스크램제트의 성능에 미치는 영향이 램제트에 비 해 적음을 뜻하며 따라서 극초음속으로 갈수록 램제트보다 스크램제트가 더 효율적임을 보여준 다. 하지만 스크램제트는 흡입구 출구 마하수 (또는 연소기 입구 마하수) 조건에 따라 비행영 역이 제한적으로 나타나므로[2] 이중램제트의 흡 입구의 형상 결정은 작동영역분배와 효율적인 성 능설계를 기반으로 하여야 한다.

\subsection{2 연소기 입구 마하수의 영향}

연소기 영역에서는 연소로 인한 열량 추가로 연소기 출구 마하수 $M_{4}=1.0$ 에 도달하는 열질식 (thermal chocking)이 발생하며 이에 따라 열량 추가율이 제한된다. 램제트의 경우 일정 압력의 연소기에서는 열질식이 발생하지 않고 전압력 손 실이 작기 때문에 연소기 입구 마하수의 영향을 크게 고려할 필요가 없지만 일정 단면적의 연소 기의 경우 열질식을 막기 위해 충분히 낮은 입구 마하수가 얻어져야 한다. 스크램제트의 경우 연 소실내 전압력 손실에 대한 영향으로 인해 입구 마하수의 선택에 대한 중요성이 훨씬 더 크다. 이러한 연소기 입구 마하수의 선택은 당량비에 따라서도 민감하게 변한다.

Fig. 5와 6은 일정 단면적을 가지는 연소기와 일정 압력을 가지는 연소기에 대한 비행 마하수 와 연소기 입구 마하수에 따른 열질식에 의한 한 계를 당량비에 따라 나타내고 있다.

일정한 단면적의 연소기의 경우(Fig. 5) 램제트 와 스크램제트 모두 열질식에 의한 연소기 입구 마하수의 한계가 존재하며 당량비 증가에 따라 적용 가능한 $M_{2}$ 의 영역도 축소된다. 램제트의 경우 당량비 $\phi=0.9$ 를 기준으로 $M_{2} \leq 0.15$ 의 매우 낮은 입구 마하수 조건에서 주어진 당량비 조건에 따른 열질식의 제약으로부터 자유로울 수 있다. 스크램제트의 경우 당량비가 증가함에 따

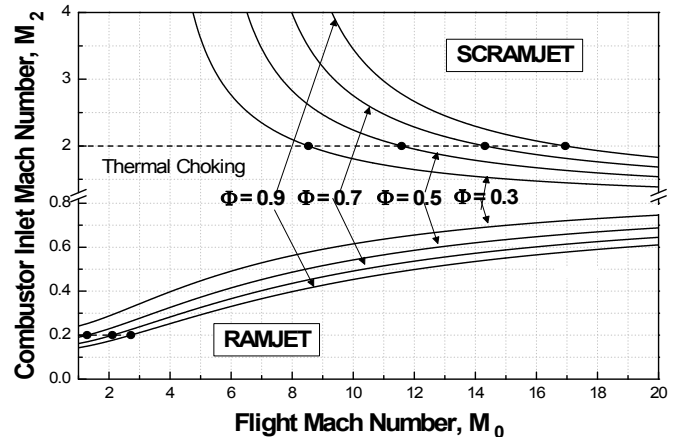

Fig. 5. Combustor Inlet Mach Number Limit for Ramjet/Scramjet with Constant $A_{c}$

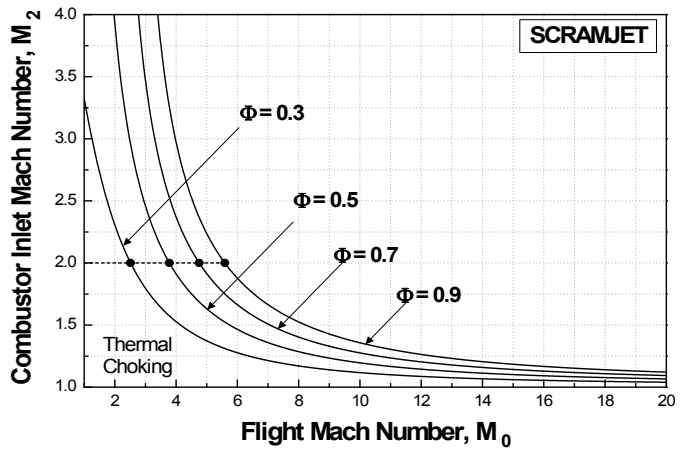

Fig. 6. Combustor Inlet Mach Number Limit for Scramjet with Constant $P_{c}$

라 열량추가율의 한계로 인해 비행마하수의 범위 도 함께 감소하는 것을 알 수 있으며, 램제트의 경우와 비교할 때 당량비 변화에 따른 한계특성 의 변화가 크게 나타난다.

일정한 압력을 가지는 연소기의 경우(Fig. 6) 열질식에 의한 열량추가율의 제한은 스크램제트 의 경우만 존재한다. 그에 따른 연소기 입구마하 수의 한계치는 일정한 단면적을 가지는 연소기와 마찬가지로 당량비 증가에 따라 증가하며 비행가 능 영역도 감소한다. 하지만 동일한 입구 마하수 에 대해 최소 비행 마하수를 비교해 볼 때, 일정 한 압력의 연소기의 경우가 더 낮은 저극초음속 영역에서부터 적용 가능함을 알 수 있다. $M_{2}=2$ 에서 당량비 $\phi=0.9$ 의 한계 비행 마하수는 일정 한 단면적의 연소기는 $M_{0}=8.5$ 로 이 보다 낮은 영역에서는 열질식이 발생한다. 그러나 일정한 압력의 연소기에서는 $M_{0}=5.7$ 로 비행가능영역이 크게 증가하게 된다.

연소기 입구 마하수는 엔진의 작동특성 뿐만 아니라 흡입구 설계에 있어서도 주요한 변수이 다. 따라서 비행조건과 작동영역에 따른 최적의 연소기 입구 마하수를 선정하는 것이 전체 엔진 
의 성능측면에서도 중요하다. 이를 위하여 최대 열효율을 갖도록 하는 최적의 연소실 입구 마하 수를 선정하는데 이는 식 (11)의 열효율의 정의 로부터 얻어진다[5].

$$
\eta_{t h}=\frac{\theta-1}{f \eta_{B} H_{f} / c_{p} T_{0}}\left[\eta_{c} \eta_{e}\left(1+\frac{f \eta_{B} H_{f}}{c_{p} T_{0}} \frac{1}{\theta}\right)-1\right]
$$

따라서 최대 열효율을 가지기 위한 온도비는 다음과 같다.

$$
\begin{aligned}
& \frac{\partial \eta_{t h}}{\partial \theta}= 0 \rightarrow \theta_{\text {opt }}=\sqrt{\left(\frac{\eta_{0}}{1-\eta_{0}} \frac{f \eta_{B} H_{f}}{c_{p} T_{0}}\right)} \\
&\left(\eta_{t h}\right)_{\max }=\eta_{0}\left(1-\frac{1}{\theta_{\text {opt }}}\right)^{2}
\end{aligned}
$$

Fig. 7은 일정한 흡입구 손실계수 $\eta_{0}=0.86$ 에 대하여 비행 마하수와 연소실 흡입구 마하수에 따른 열효율의 변화를 나타낸다. 주어진 해석조 건에서 최적의 온도비는 약 6.45 이며 최대 열효 율은 약 0.614 이다. 그러나 최대 열효율을 얻을 수 있는 비행영역은 연소기 입구 마하수 $M_{2}$ 에 따라 변한다. 램제트의 경우 $M_{2}=0.2$ 일 때 약 $M_{0}=5.2$ 에서 최대 열효율을 얻을 수 있다. 스크 램제트의 경우 $M_{2}=1.5$ 일때 $M_{0} \geq 5.85$ 의 영역에 서 램제트보다 높은 열효율을 나타내며 $M_{0}=6.45$ 에서 최대 열효율을 갖는다. $M_{2}$ 가 증가 할수록 최대 열효율을 얻을 수 있는 비행 마하수 는 증가한다.

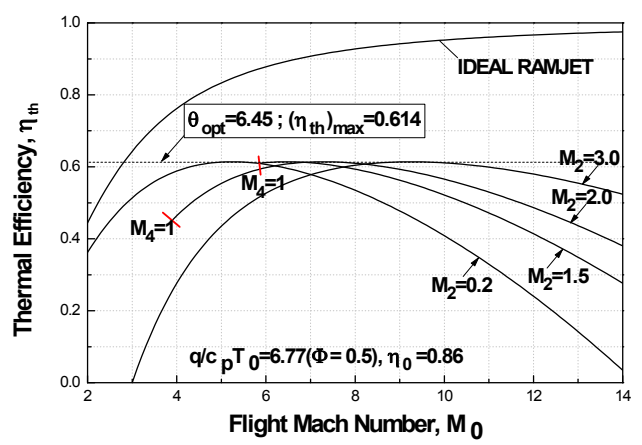

Fig. 7. Thermal Efficiency for Various values of $M_{2}$

\subsection{3 연소실 형상 및 당량비의 영향}

연소실 형상 및 당량비(연료분사량)에 따른 성 능의 변화를 살펴본다. 연소기 입구 마하수는 램 제트의 경우 $M_{2}=0.2$ 를, 스크램제트의 경우 $M_{2}=2.0$ 에 대하여 당량비 $\phi=0.3 \sim 0.9$ 로 변화
시키면서 해석을 수행했다.

먼저 일정한 압력을 갖는 연소기에 대한 해석 결과를 살펴보도록 한다.

Fig. 8과 9는 일정한 압력의 연소기의 비행 마하 수와 당량비에 따른 열효율과 추력비의 변화를 보 여준다. 램제트/스크램제트 모두 당량비 증가에 따 라 열효율 및 추력비는 향상된다. 선 $\mathrm{AB}$ 는 스크램 제트가 램제트보다 우수한 성능을 나타내기 시작 하는 작동천이 마하수를 표현하며 당량비 증가에 따라 천이마하수도 증가한다. 또한 열질식이 존재 하는 스크램제트의 한계 마하수도 당량비 증가에 따라 증가하는 것을 확인 할 수 있다.

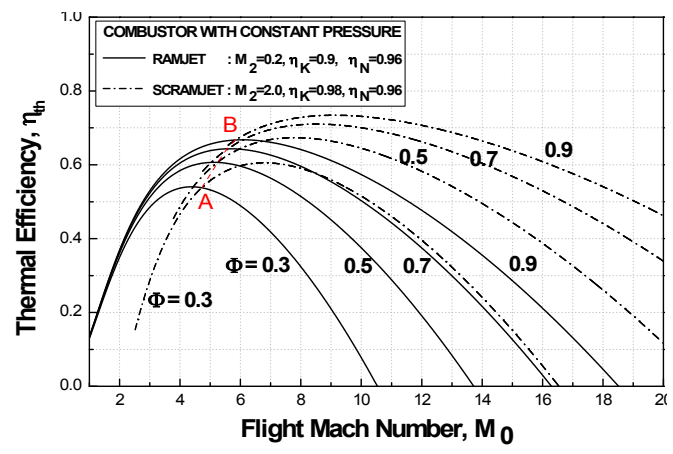

Fig. 8. Thermal Efficiency of Constant $P_{c}$

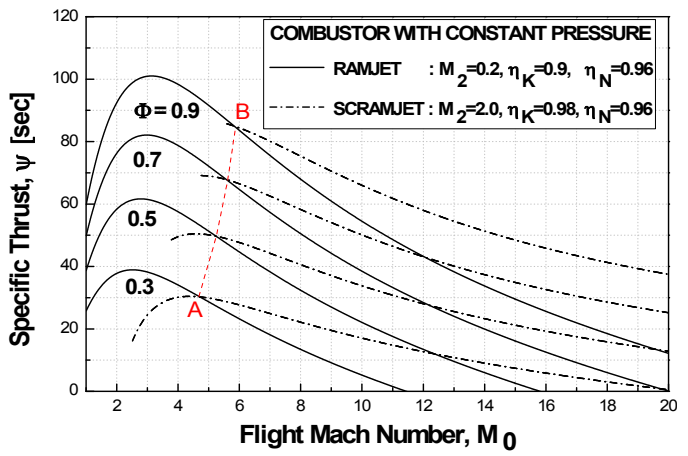

Fig. 9. Specific Thrust of Constant $P_{c}$

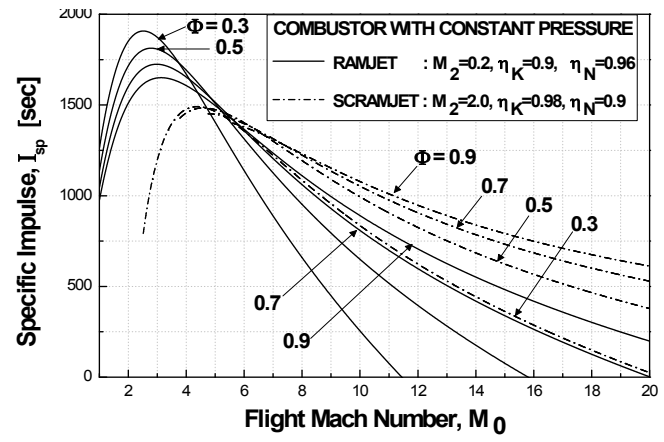

Fig. 10. Specific Impulse of Constant $P_{c}$ 
Fig. 10은 일정한 압력을 가진 연소기의 당량 비 변화에 따른 비추력에 대한 해석결과이다. 열 효율과 비추력은 당량비 증가에 따라 각 성능도 함께 증가하는 반면에 비추력은 약 마하 4 이하 의 영역에서는 당량비가 낮을수록 비추력이 높은 반면, 약 마하 6이상에서는 이러한 현상이 역전 되는 것을 확인 할 수 있다. 즉, 비행조건에 따라 최적의 성능을 얻기 위해서는 서로 다른 당량비 를 적용하여야 함을 의미한다.

Fig. 11-13은, 일정한 압력을 가지는 연소기 해 석과동일한 조건으로, 일정한 단면적을 가지는 연소기에 대한 열효율, 추력비 및 비추력의 결과

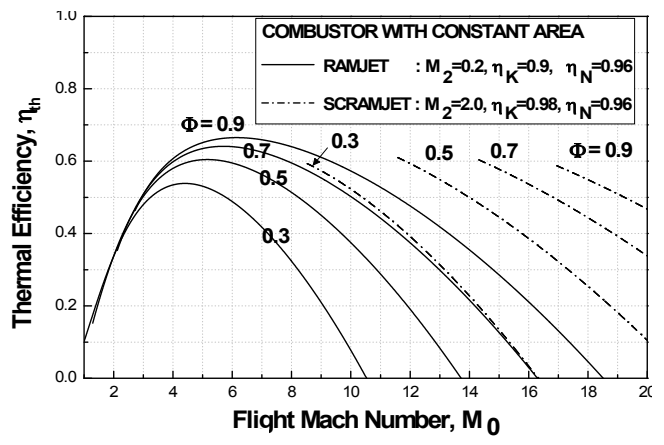

Fig. 11. Thermal Efficiency of Constant $A_{c}$

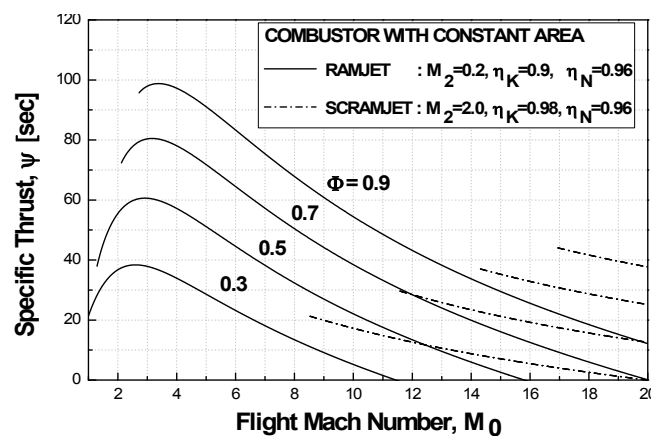

Fig. 12. Specific Thrust of Constant $A_{c}$

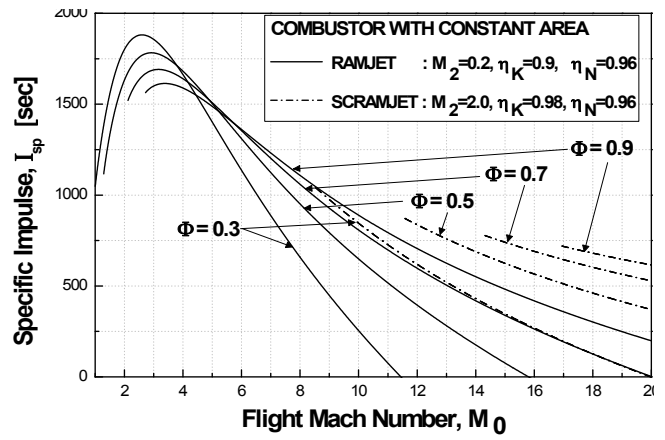

Fig. 13. Specific Impulse of Constant $A_{c}$
를 나타낸 것이다. 램제트의 경우 각 성능변수의 해석결과는 일정압력의 연소기의 경우와 거의 유 사한 것을 알 수 있다. 다만, 일정단면적의 연소 기의 경우 램제트 작동조건에서도 열질식에 의한 한계가 존재하며 당량비가 증가할수록 이에 따른 한계 비행마하수가 증가한다. 반면 스크램제트는 일정 압력의 연소기의 경우에 비해 열질식에 의 한 한계영역에서 큰 차이를 보인다. 일정 압력의 연소기의 경우 열질식이 발생하기는 하나 마하 4 이상의 초음속 영역과 마하 6 의 저극초음속 영역 에서부터 극초음속 영역까지 작동 가능한 반면, 일정 단면적의 연소기의 경우 저극초음속 영역에 서는 열질식이 발생하며 마하 8이상의 극초음속 영역에서 효율적으로 작동할 수 있다. 또한 일 정 압력의 연소기의 경우 스크램제트 연소기 입 구 마하수를 $M_{2}=2.0$ 로 선정하여도 동일 당량 비 대비 램제트/스크램제트의 작동 천이 마하 수가 존재하는 반면 일정 단면적의 연소기의 경 우 $M_{2}=2.0$ 에서는 작동천이지점을 얻을 수 없 으며 작동천이를 위해서는 당량비를 함께 변화 시키거나 열량추가율의 한계에 의한 연료의 손 실을 감수해야 함을 알 수 있다. 동일한 당량비 조건에서 작동 천이점을 얻기 위해서는 스크램 제트의 연소기 입구 마하수를 증가시켜야만 한 다.

연소실 형상 및 당량비에 따른 열효율과 추력 비, 비추력의 결과로부터 각 성능변수는 비행마 하수가 증가함에 따라 증가하여 최대성능지점에 도달한 후 일정 마하수 이상에서는 오히려 감소 함을 알 수 있다. 하지만 각 성능변수들이 최대 의 성능을 갖는 비행마하수가 서로 다르게 나타 난다. 즉, 한가지 엔진으로 모든 성능을 최대로 갖는 엔진을 설계할 수는 없으며 엔진의 목적과 요구 성능에 따라 이들을 절충하여 최적의 설계 점을 선정하는 것이 중요하다.

\subsection{4 추진노즐 효율의 영향}

추진노즐에서의 손실이 없다면 최대 추력을 얻기 위한 노즐 출구조건은 출구압력과 대기압력 이 같은 이상팽창조건이다. 하지만 이상팽창을 위해서는 그에 요구되는 노즐의 팽창비가 매우 커서 노즐출구의 면적이 흡입구나 연소기 단면적 보다 훨씬 크게 될 수 있다. 이는 엔진의 무게와 항력을 증가시켜 엔진의 성능을 저하시키는 요인 으로 작용한다. 이러한 문제로 실제 엔진 설계시 에는 노즐 출구 압력을 대기 압력보다 다소 높은 부족팽창 조건으로 노즐을 설계하는데 실제 비행 시에는 이러한 조건이 유리하게 작용함을 다음의 


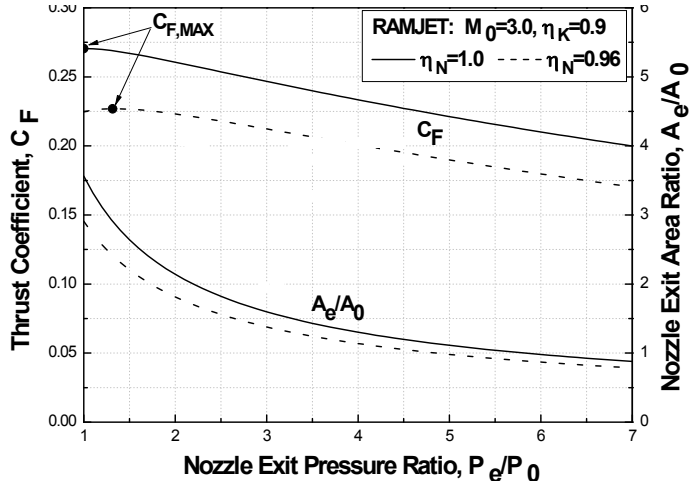

Fig. 14. Effect of Exhaust Nozzle Pressure Ratio on $C_{F}$ and $A_{e} / A_{0}$ in Case of a Ramjet

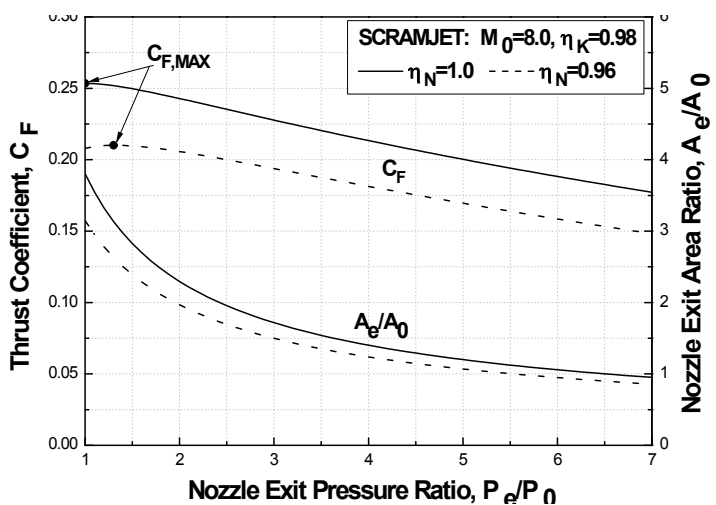

Fig. 15. Effect of Exhaust Nozzle Pressure Ratio on $C_{F}$ and $A_{e} / A_{0}$ in Case of a Scramjet

결과로부터 확인 할 수 있다. Fig. 14-15는 노즐 효율계수에 따른 램제트와 스크램제트의 노즐 면 적비와 추력계수의 영향을 보여준다. 노즐 효율 의 감소로 추력계수는 감소하며, 최대 추력계수 는 다소 부족팽창인 영역에서 얻어진다. 이러한 경향은 램제트와 스크램제트 모두 동일하다.

\section{III. 결 론}

본 연구에서는 이중램제트 설계인자를 파악하 기 위하여 램제트/스크램제트 각 엔진에 대하여 열역학적 사이클 해석을 바탕으로 각 성능인자의 영향에 따른 성능민감도를 분석하였다. 해석을 통한 주요 결론은 다음과 같다.

1. 흡입구 성능은 램제트 엔진의 성능을 결정 하는 주요인으로 엔진 성능을 최대화하기 위해서
는 흡입구에서의 전압력 회복률을 최대화하여야 한다. 또한 극초음속 비행영역으로 갈수록 흡입 구의 효율이 엔진의 성능에 크게 영향을 미치며 이와 더불어 충격파에 따른 압축공기 특성의 변 화도 고려하여야 한다.

2. 연소기 입구 마하수는 열질식의 발생으로 인해 제약된다. 램제트의 경우 연소기 입구마하 수는 일정 단면적의 연소기에서만 한계조건이 존 재하며 여기서 열량추가율의 한계를 벗어나기 위 해서는 연소기 입구 마하수가 충분히 낮아야 한 다. 스크램제트의 경우 두 연소기 모두 열질식이 발생하며 연소기 입구 마하수가 높을수록 보다 넓은 비행영역을 확보할 수 있다.

3. 램제트의 경우 연소기 형상에 따른 성능의 차이는 크지 않으나 일정 단면적의 연소기에서는 열질식에 따른 열량추가율의 제한을 고려하여야 한다. 스크램제트의 경우 일정압력의 연소기에 비해 일정단면적의 연소기가 열질식에 의한 비행 영역의 제한이 심하며 한계 비행마하수는 당량비 조건에 따라 민감하게 변하기 때문에 비행영역에 따른 작동조건 설정에 유의하여야 한다.

4. 추진노즐 내 유동이 non-isentropic일 때 최 대 추력은 노즐 출구압력이 대기압력 보다 다소 높은 조건에서 얻어지며, 이때 노즐의 팽창비는 이상 팽창시의 팽창비에 비해 크게 감소하여 엔 진 노즐의 체적과 무게, 항력을 감소시키는 효과 를 가져 온다.

5. 열질식, 최적 성능, 램제트에서 스크램제트 로의 작동천이 조건 등은 엔진의 비행속도, 연소 기의 형상, 당량비, 흡입구의 성능 인자 등에 따 라 민감하게 변하므로 이중램제트 설계 시 램제 트/스크램제트의 성능인자에 따른 변화 추이와 민감도를 종합적으로 검토하여 램제트/스크램제 트의 작동영역분배를 결정하여야 한다.

\section{참고문헌}

1) 차봉준, 김상훈, 양수석, “공기흡입형 고속 추진기관 기술동향", 항공우주산업기술동향, 4 권 1호, 2006, pp. 44-54.

2) 김선경, 전창수, 성홍계, “이중램제트(이중연 소/이중모드)엔진을 위한 램제트/스크램제트의 작동영역분배 및 성능민감도분석 Part I . 작동 영역분배", 한국항공우주학회지, 제 38 권 제6호.

3) 변종렬, 성홍계, 윤현걸, “초고속 순항 추진 기관(램제트/스크램제트)의 성능인자에 대한 해 석적 연구", 한국추진공학회 추계학술대회, 2005, pp. 141-146. 
4) E. T. Curran, J. Leingang, L. Carreiro, and D. Petters, "Further Studies of Kinetic Energy Methods in High Speeds Ramjet Cycle Analysis", AIAA paper 9982-3805, 1992.

5) H. Wittenberg, "Some Fundamentals on the Performance of Ramjets with Subsonic and
Supersonic Combustion", TNO Prins Maurits Laboratory, 2000.

6) W. F. Ng, "Real Gas Effects on the Numerical Simulation of a Hypersonic Inlet", Journal of Propulsion, July-August 1986, pp. 381-382. 